\title{
Paradigm Shift: A Call for Conceptualization of a Fast Fashion Sustainable Business Model
}

\author{
Michelle Burton, Iowa State University \\ Rachel Eike, Iowa State University \\ Beth Myers, Georgia Southern University
}

Key Words: Business Model, Sustainability, Apparel and Textile Industry, Fast Fashion

\section{Introduction}

The clothing and textile industry, valued at over $\$ 1$ trillion worldwide employs almost 26 million people and contributes to approximately $7 \%$ of world exports (Allwood et al., 2006). The textile industry is one of the largest industries worldwide and a considerable contributor to GHG (greenhouse gas) emissions and climate change (Zaffalon, 2010). By 2050, it is predicted that climate change issues could become monumental threats, impacting access to basic necessities of life: food, water, and shelter (Zaffalon, 2010).

\section{Fast Fashion and Consumption}

Fast fashion is characterized by inexpensive and easily disposable (throwaway) items, offering products with multiple seasons and new inventory on a weekly basis, instead of the common two seasons per year (Birtwistle \& Moore, 2007). The current business model employed by low-cost fast fashion retailers yields substantial negative environmental and social sustainability outputs (McNeill \& Moore, 2015), and consumers are at a point where they no longer invest in clothing at rates in which garments are produced (Howland, 2019). This high-turnover in product further exacerbates undesirability and obsolescence and an increasingly unsustainable fashion industry. The fast fashion business model employs workers in developing nations where employees work long hours, earn low wages, employ children in their labor workforce, and operate in facilities where health and safety issues exist (Madsen et al., 2007). Low quality, decreased prices, and faster trend cycles are all contributing factors to the increase in consumption on a global level (Fletcher, 2008).

This concept paper provides a review of recent fast fashion retailer challenges and business opportunities that support the call for a proposed shift to embody a fast fashion sustainable business model (FFSBM) where focus needs to include social issues, consumer transparency, and sustainability to reform brand direction and identity. A business model change is needed to help guide and reflect the transition occurring in the industry while providing optimism for profit and growth.

\section{Page 1 of 5}

Published under a Creative Commons Attribution License (https://creativecommons.org/licenses/by/4.0/), which permits unrestricted use, distribution, and reproduction in any medium, provided the original work is properly cited.

ITAA Proceedings, \#76 - https://itaaonline.org 


\section{Consumer Shifts}

Fast fashion negatively impacts the secondhand market because there is little variation between new and old garment pricing (Morley et al., 2016). According to Lehmann et al. (2018), apparel and footwear consumption will rise to 102 million tons in 2030. Instead of recycling or repurposing, the majority of unwanted, still functional, apparel waste will end in landfills (Allwood et al., 2006; Madsen et al., 2007). The first course of action in increasing clothing sustainability is recycling or re-use because it eliminates harmful impacts to the environment such as production, clothing disposal, and processing (WRAP, 2017). Pre-ownership, rental, and refurbished products are projected to gain importance in the marketplace as customers are seeking affordability and flexible/temporary possession of clothing products (Amed et al., 2018). Consumers are moving away from complete ownership and towards models that allow newness, affordable, and sustainable options.

\section{Industry Shifts}

The industry is also experiencing changes that concern environmental and social sustainability as well as company profit. Rising wages in Asia have decreased cost efficiency that was once lucrative for apparel companies. For instance, offshore labor costs over the last decade have experienced substantial change - "in 2005, China labor costs were one-tenth of those in the US; today they are about one-third" (Amed et al., 2019, p. 86). The shifting global manufacturing landscape in combination with increased automation of product assembly will further increase costs association with production. Nike uses Grabit technology to manufacture shoe uppers in 50 seconds which is 20 times faster than humans with an investment payback period of two years (The Robot Report, 2018). Softwear also has sewbots that are able to simultaneously view and analyze moving fabric using computerized vision (Softwear Automation, 2018). Compared to other industries, apparel and textiles have lagged, until now, with advancements in automation. One reason for the recent increase in automation interest and investment is that companies have "heavily relied on low labor costs of manufacturing workers (in Asian and other low-cost sourcing markets)" (Amed et al., 2019, p. 88).

Conceptualized direction: The case for a new model

A consistent business model for fast fashion retailers doesn't exist. Previous published research heavily cites Zara's business practices (Aftab, Yuanjian, Kabir \& Barua, 2018). Furthermore, the lack of a consistent business model doesn't allow for future formal research on sustainability integration and measurement for impact. Therefore, it is suggested that the sustainable value framework by Hart and Milstein (2013) could provide a structure for a revised business model that accounts for the current state of fashion (specifically targeting the fast fashion sector), consumer shifts, and industry shifts, in what the authors are calling a 'fast fashion sustainable

Published under a Creative Commons Attribution License (https://creativecommons.org/licenses/by/4.0/), which permits unrestricted use, distribution, and reproduction in any medium, provided the original work is properly cited.

ITAA Proceedings, \#76 - https: //itaaonline.org 
business model' (FFSBM). The four dimensional strategies of the sustainable value framework include clean technology, sustainability vision, pollution prevention, and product stewardship and are linked to value-creation and organization performance. A newly proposed FFSBM would focus on increased sustainability practices and longevity that would provide affordable fashions for today's consumer. The strategies within this developed model have the potential to increase innovation and repositioning, reduce cost and risk, solidify the future growth trajectory for an apparel company, and enhance the reputation and legitimacy of the organization. All of these components are critical to shareholder value and ultimately sustainable value.

Changes in apparel manufacturing and retail landscapes are rapidly occurring and in order for companies to stay relevant and prosper, a new approach to business is needed. After analysis of consumer and industry shifts, a call for a conceptualized method for a sustainable business model is proposed. Future directions to create the FFSBM include interviews with consumers and industry leaders, consumer surveys, and a thorough analysis of consumer and industry data.

Page 3 of 5

(c) 2019 The author(s). Published under a Creative Commons Attribution License (https://creativecommons.org/licenses/by/4.0/), which permits unrestricted use, distribution, and reproduction in any medium, provided the original work is properly cited.

ITAA Proceedings, \#76 - https://itaaonline.org 
References

Aftab, M., Yuanjian, Q., Kabir, N., \& Barua, Z. (2018). Super Responsive Supply Chain: The Case of Spanish Fast Fashion Retailer Inditex-Zara. International Journal of Business and Management, 13(5), 212.

Allwood, J., Laursen, S. Malvido de Rodriguez, C. \& Bocken, N. (2006). Well Dressed? The Present and Future Sustainability of Clothing and Textiles in the United Kingdom. Retrieved from https://www.ifm.eng.cam.ac.uk/uploads/Resources/Other_Reports/UK textiles.pdf

Amed, I., Berg, A., Balchandani, A., Andersson, J., Hedrich, A., \& Young, R. (2019). The State of Fashion. Retrieved from https://www.mckinsey.com/industries/retail/our-insights/thestate-of-fashion-2019-a-year-of-awakening

Birtwistle, G. \& Moore, C. (2007). Fashion clothing - where does it all end up? International Journal of Retail \& Distribution Management, 35, pp. 210-216.

Fletcher, K. (2008). Sustainable Fashion and Textiles: Design Journeys. Earthscan/James \& James, London.

Hart, S.L. \& Milstein, M.B. (2003). Creating sustainable value. Academy of Management Executive 17(2), pp. 56-67.

Howland, D. (2019). H\&M to shutter 160 stores amid profit slump. Retrieved from https://www.retaildive.com/news/hm-to-shutter-160-stores-amid-profit-slump/547417/

Lehmann, M., Tärneberg, S., Tochtermann, T., Chalmer, C., Eder-Hansen, J., Seara, J.F., Boger, S., Hase, C., Berlepsch, V.V., \& Deichmann, S. (2018). Pulse of the Fashion Industry. Retrieved from https://www.globalfashionagenda.com/initiatives/pulse/\#

Madsen, J., Hartlin, B., Perumalpillai, S. Selby, S. \& Aumonier, S. (2007). Mapping of Evidence on Sustainable Development Impacts that Occur in the Life Cycles of Clothing: A Report to the Department for Environment, Food and Rural Affairs. Environmental Resources Management [ERM] Ltd. Defra, London.

McNeill, L., \& Moore, R. (2015). Sustainable fashion consumption and the fast fashion conundrum: Fashionable consumers and attitudes to sustainability in clothing choice. International Journal of Consumer Studies, 39(3). https://doi.org/10.1111/ijcs.12169

Morely, N., Slater, S., Russell, S., Tipper, M. \& Ward, G.D. (2006) Recyling of low grade Page 4 of 5

Published under a Creative Commons Attribution License (https://creativecommons.org/licenses/by/4.0/), which permits unrestricted use, distribution, and reproduction in any medium, provided the original work is properly cited.

ITAA Proceedings, \#76 - https: //itaaonline.org 
clothing waste. Retrieved from http://www.inno-therm.com/wp content/uploads/2013/10/Recycle-Low-Grade-Clothing.pdf

SoftWear Automation. (2018). Products. Retrieved from http://softwearautomation.com/products/.

The Robot Report. (2018). Grabit robots use static electricity to make Nikes faster than humans. Retrieved from https://www.therobotreport.com/grabit-robots-make-nikes-faster-humans/

WRAP (2017). Valuing our clothes: The cost of UK Fashion. The true cost of how we design, use and dispose of clothing in the UK. Retrieved from http://www.wrap.org.uk/sites/files/wrap/valuing-our-clothes-the-cost-of-ukfashion_WRAP.pdf

Zaffalon, V. (2010). Climate change, carbon mitigation and textiles. Textile World, 16(4), 3435 . 